\title{
Can insect data be used to infer areas of endemism? An example from the Yungas of Argentina
}

\author{
¿Pueden utilizarse los datos de insectos para inferir áreas de endemismo? Un ejemplo de \\ las Yungas de Argentina
}

\author{
FERNANDO R. NAVARRO, FABIANA CUEZZO*, PABLO A. GOLOBOFF, CLAUDIA SZUMIK, MERCEDES \\ LIZARRALDE DE GROSSO \& M. GABRIELA QUINTANA
}

\begin{abstract}
Consejo Nacional de Investigaciones Científicas y Técnicas - Instituto Superior de Entomología "Dr. Abraham Willink" Facultad de Ciencias Naturales e Instituto Miguel Lillo UNT, Miguel Lillo 205, 4000 San Miguel de Tucumán, Tucumán, Argentina

*Corresponding author: fcuezzo@csnat.unt.edu.ar
\end{abstract}

\begin{abstract}
The main purpose of this study is to analyze whether areas of endemism can be characterized quantitatively by using insects, which are typically much more poorly sampled than vertebrates or plants. For this, an optimality criterion in the search for endemic areas was used to analyze approximately 1,100 georeferences from 288 species of holometabolous insects found in the study region, the Yungas (a very moist, montane rainforest), located in north-western Argentina. The optimality criterion is implemented with the programs NDM/VNDM, used to evaluate areas of endemism (i.e. a set of cells defined by two or more endemic species). Five grid sizes were used, three square $\left(1^{\circ}, 0.5^{\circ}\right.$, and $\left.0.25^{\circ}\right)$ and two rectangular $\left(0.25^{\circ} \times 0.5^{\circ}\right.$ and $0.5^{\circ} \times 0.25^{\circ}$ ). In agreement with the traditional biogeographic proposal, the results of the present study indicate that the Yungas can be characterized as a biogeographic unit with its own identity. Twenty six areas related to Yungas have shown 23 species of insects (in 14 families) as endemic, restricted to Yungas environment, and 46 species (in 10 families) as endemic, present in Yungas and surrounding habitats. Our analysis suggests that the use of insects to identify areas of endemism is a powerful tool, even considering the current fragmentary knowledge of these groups in South America. Given that there is no criterion to choose an optimal grid size, the use of different grid sizes is crucial; medium and small sizes are highly recommended because both identify seemingly different patterns. The quantitative method used here is useful to identify areas of endemism, such as disjoint areas or partially overlapping areas, which are difficult to see with other traditional biogeographic methods.
\end{abstract}

Key words: biogeography, distribution patterns, Montane forests, NDM/VNDM.

\section{RESUMEN}

El objetivo principal de este trabajo es analizar si las áreas de endemismo pueden ser caracterizadas cuantitativamente utilizando insectos, los cuales generalmente se encuentran mucho más pobremente muestreados que vertebrados y plantas. La búsqueda de áreas de endemismo fue realizada utilizando un criterio de optimalidad sobre aproximadamente 1,100 georreferencias de 288 especies de insectos holometábolos presentes en la región de estudio. Esta corresponde al noroeste de la Argentina, específicamente en las Yungas (un bosque lluvioso montano muy húmedo). El software NDM/VNDM, que aplica dicho criterio de optimalidad, fue usado para buscar áreas de endemismo (i.e. conjuntos de celdas definidos por dos o más especies). Se utilizaron cinco tamaños de grilla: tres cuadrados $\left(1^{\circ}, 0.5^{\circ}\right.$ y $\left.0.25^{\circ}\right)$ y dos rectangulares $\left(0.25^{\circ} \mathrm{x} 0.5^{\circ}\right.$ y $0.5^{\circ} \mathrm{x}$ $0.25^{\circ}$ ). Los resultados de este estudio indican que las Yungas pueden ser caracterizadas como una unidad biogeográfica con identidad propia y estos resultados concuerdan con propuestas biogeográficas previas. Se obtuvieron 26 áreas de endemismo con 23 especies endémicas de insectos (en 14 familias) restringidas a Yungas y 46 especies (en 10 familias) endémicas, presentes en Yungas y hábitats adyacentes. Nuestro análisis sugiere que el uso de insectos puede ser una herramienta poderosa para identificar áreas de endemismo, aun considerando lo fragmentario del conocimiento actual de estos grupos en América del Sur. El uso de diferentes 
tamaños de grilla fue crucial. Tamaños pequeños y medianos son altamente recomendados para identificar patrones diferentes. El método cuantitativo utilizado permitió identificar áreas de endemismo difíciles de reconocer con métodos biogeográficos tradicionales, tales como áreas disyuntas o parcialmente superpuestas.

Palabras clave: biogeografía, Bosque Montano, patrones de distribución, NDM/VNDM.

\section{INTRODUCTION}

Many biogeographic proposals that describe different regions, provinces, or domains in South America have been put forward (Cabrera 1971, Cabrera \& Willink 1973, Hueck 1978, Morrone 2000, 2001, 2006, Willink 1991). Although based on the vast experience of one or more specialists, most of these compilations are of a qualitative nature and based solely on the authors' common sense. As a result, the validity of many of the areas proposed in these studies is difficult to reformulate and/or assess. Such is the case of Yungas, a territory which covers over $4,000 \mathrm{~km}$ from Venezuela to the north-west of Argentina, which has been characterized almost exclusively by its flora (Cabrera 1971, Hueck 1978).

According to some authors (Cabrera \& Willink 1973, Brown 1995, Graham 1995, Prado 1995), the Yungas are a heterogeneous unit, whose major differences regarding fauna and flora are the result of climatic and historic factors. Cabrera \& Willink (1973) proposed that the Yungas can be characterized on the basis of floristic components (even when exclusive floral elements are scanty), and that the fauna is mostly composed of taxa from nearby areas (without unique elements); this is particularly clear in north-western Argentina, where the Yungas display a combination of plants from arid and semiarid Chaco and the Paranaense forests.

In contrast to Cabrera \& Willink (1973), Morrone $(2000,2001,2006)$ compiled a list of apparently endemic taxa, which includes some insect species. However, under closer examination, most of the taxa in his list cannot be used to characterize the Yungas as a unit, since they are present only in small sectors of the Yungas. For example, Nothocercus nigrocapillus (Tinamidae) is only present in Perú and part of Bolivia (Fjeldsa \& Krabbe 1991).

The proposals made so far disagree both on the role given to fauna and flora in characterizing the Yungas and on the number of boundaries of regions and provinces.
However, the biogeographers generally agree upon the fact that these biogeographic units both show a characteristic landscape and have endemic species.

Areas of endemism are the study units in biogeographic and conservation research, but their recognition has been hindered by the lack of appropriate methodology. The most commonly used methods to determine areas of endemism are Parsimony Analysis of Endemicity (Morrone 1994) and UPGMA (Linder 2001). However, both methods were developed to identify patterns outside the field of biogeography. The method developed by Szumik et al. (2002) and Szumik \& Goloboff (2004) attempts to remedy this situation by applying an explicit criterion of optimality to evaluate areas of endemism, that is, the distributional congruence of taxa (Platnick 1991). This includes the spatial component lacking in parsimony or UPGMA, and is implemented in the programs NDM/VNDM (available at http://www.zmuc.dk/public/ phylogeny/endemism).

Our data set consists of about 1100 records of 288 species for some important insect groups (Hymenoptera, Diptera, and Lepidoptera) which are clearly much more poorly sampled than vertebrates or plants (see Aagensen et al. 2009). Additionally, the information on insect distribution in South America clearly indicates that we are really far away from a perfectly sampled zone (as in European or North American biodiversity studies).

This work attempts to evaluate whether applying formal methods leads to reasonable conclusions despite the low sampling data. The question quantitatively posed is whether such a low sampling density is enough for reaching conclusions which are qualitatively similar to those established in previous, informal analyses. Finding patterns, the Yungas in this case, previously described by prestigious biogeographers is a powerful hint of the potentiality of the method. It is important to remark that the sole assumption of this method is that concordance on the distribution of 
various species would indicate the presence of endemism, which is the result of historical and ecological factors (Szumik et al. 2002) The endemic species should have significantly similar distributions, and to be considered as endemic of an area, a species must be found throughout the area; that is to say, species with non congruent distributions cannot be seen as part of the same phenomenon or the same area of endemism (Casagranda et al. 2009).

\section{METHODS}

\section{Study region}

The Yungas, one of the most important biogeographic areas present in South America, reach on the north, to Venezuela (or only to Perú, according to some authors), and, on the south, the northwest of Argentina. They are located on the eastern slopes of the Andes, between 300 and 3,500 m of altitude (Cabrera 1971, Cabrera \& Willink 1973, Brown 1995, Morales et al. 1995, Morrone 2000, 2001, 2006). In Argentina they span from north to south along over $600 \mathrm{~km}$, with a surface of 4.5 million ha (in the provinces of Jujuy, Salta, Tucumán and Catamarca; see Fig. 1), and have an altitudinal range of 400 to $3000 \mathrm{~m}$ (Cabrera 1976). Over 150,000 ha of Argentinean Yungas are protected areas (Fig. 1) like El Rey, Calilegua, Baritú, San Javier, etc.

Regarding their flora and landscape, many authors recognize three altitudinal levels: Premontane Forest (300-600 m) (also known as "Transitional Forest"), Montane Forest (600$1,500 \mathrm{~m}$ ) (with two distinct forest types: lower montane forest or "Selva Basal", from 900 to $1200 \mathrm{~m}$, and upper montane forest or "Selva de Mirtáceas", from 1,200 to 1,600 m), and Montane Cloud Forest (1,500-3,000 m) (Cabrera 1971, Brown 1995, Prado \& Gibbs 1993).

Other authors (Brown \& Ramadori 1989, Morales et al. 1995) divide the Argentinean Yungas into three sectors: north, center and south (Fig. 1). The northern Yungas sector lies between $22^{\circ} 00^{\prime}$ and $23^{\circ} 50^{\prime} \mathrm{S}$ and comprise part of the Argentine provinces of Salta and Jujuy. The central Yungas sector lies between $23^{\circ} 50^{\prime}$ and $25^{\circ} 50^{\prime} \mathrm{S}$. The southern sector Yungas lies between $25^{\circ} 20^{\prime}$ and $28^{\circ} 52^{\prime} \mathrm{S}$ and include part of Salta, Tucumán and Catamarca (Fig. 1).

\section{Taxa used in this study}

Our data set consists of about 1,100 records of 288 species (with some species having more than 20 records, and others just two or three). This means that the number of records per 100 square kilometers of our data set is 2.4. However, the sampling density in biogeographic studies of this kind, which rely on taxonomic rather than ecological information, is usually very low; when reported, it is typically as low as or lower than the density in the present study (e.g. 1.6 records $100 \mathrm{~km}^{-2}$ in Crisp et al. (2001) analysis of flora of Australia; 0.24 records $100 \mathrm{~km}^{-2}$ in Löwenberg-Neto \& Barros de Carvalho's (2004) analysis of flora and insects of South of Brazil; 0.2 records $100 \mathrm{~km}^{-2}$ in Domínguez et al. (2006) analysis of coleoptera of Patagonia; $\sim 0.042$ records $100 \mathrm{~km}^{-2}$ in Quijano et al. (2006) analysis of Piper in the Neotropical Region; 1.64 records $100 \mathrm{~km}^{-2}$ in Rovito et al. (2004) analysis of Senecio in Central Chile).

Three orders of holometabolous insects have been included in this study: Lepidoptera, Diptera and Hymenoptera. Of the 288 species included here 31 belong to two families of Lepidoptera, 140 to 24 families of Diptera, and 117 to Hymenoptera (Formicidae). See Table 1 to 6 for details. The records used for those species come from specimens of the collection in the Instituto-Fundación Miguel Lillo, Argentina, as well as recent reviews and catalogs on these families (Papavero 19661984, Kempf 1972, Lizarralde de Grosso 1989, Poole 1989, Brandão 1991, Cuezzo 1998, Lizarralde de Grosso 1998, Scoble 1999). All the records were georeferenced (using plane coordinates), with information supplied by the Instituto Geográfico Militar (http:// www.igm.gov.ar) and Biolink (http:// www.biolink.csiro.au). We include records not only from Yungas but also from surrounding areas (e.g. Chacoan, Espinal and Paraná subregion). Cuezzo et al. (2007) provide preliminary information related to this paper.

\section{Identification of areas of endemism}

The data matrix of 288 species and 1092 georeferences was analyzed using the gridbased method to identify areas of endemism proposed by Szumik et al. (2002) and Szumik 


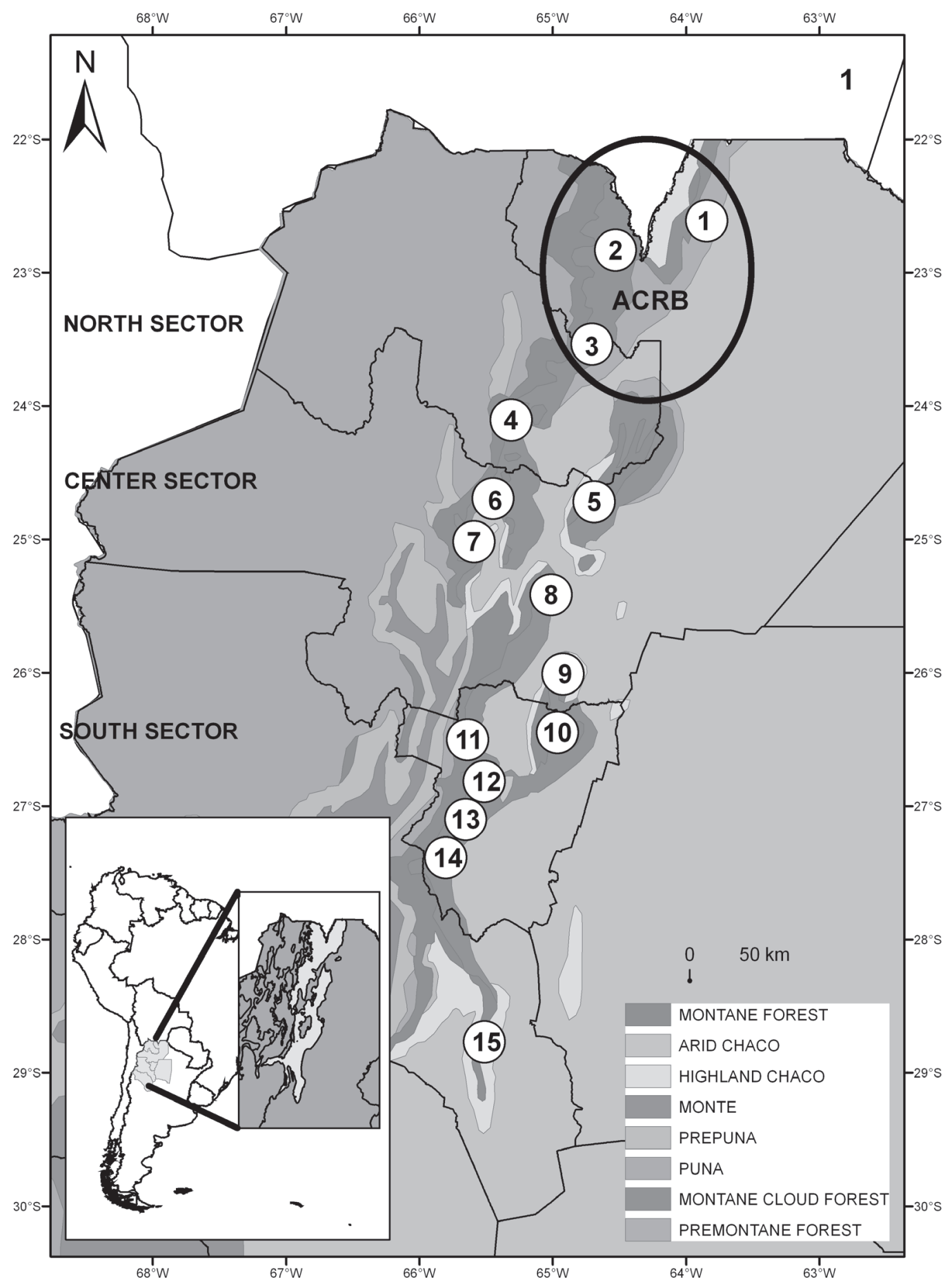

Fig. 1: Map showing the study region: 1: Acambuco. 2: Parque Nacional Baritú. 3: Parque Nacional Calilegua. 4: Potrero de Yala. 5: Parque Nacional El Rey. 6: Valle de San Lorenzo. 7: Valle de Lerma. 8: Sierra de Metán. 9: Sierra de la Candelaria. 10: Sierra del Nogalito. 11: Sierras Centrales de Tucumán. 12: Sierras de San Javier. 13: Quebrada del Río Los Sosa. 14: Sierra del Aconquija. 15: Sierra de Ancasti. ACRB: Alta Cuenca del Río Bermejo.

Mapa mostrando la región de estudio: 1: Acambuco. 2: Parque Nacional Baritú. 3: Parque Nacional Calilegua. 4: Potrero de Yala. 5: Parque Nacional El Rey. 6: Valle de San Lorenzo. 7: Valle de Lerma. 8: Sierra de Metán. 9: Sierra de la Candelaria. 10: Sierra del Nogalito. 11: Sierras Centrales de Tucumán. 12: Sierras de San Javier. 13: Quebrada del Río Los Sosa. 14: Sierra del Aconquija. 15: Sierra de Ancasti. ACRB: Alta Cuenca del Río Bermejo. 


\section{TABLE 1}

Specific composition of areas of endemism considering Yungas as a unit [Abbreviations are as follows (EY: endemic species that belong exclusively to Yungas; $\mathrm{Y}+\mathrm{OE}$ : species present both in

Yungas and in other environments; NBY: species which do not belong to Yungas); (PRF:

Premontane Forest; MFSB: Montane Forest (Selva Basal); MFSM: Montane Forest (Selva de Mirtaceas); MCF: Montane Cloud Forest; Gr: grasslands; $\mathrm{ArCH}$ : Arid or semiarid Chaco; $\mathrm{HiCH}$ : Highland or Montane Chaco; Mo: Monte; Prpu: Prepuna)].

Composición específica de áreas de endemismo resultantes en relación a las Yungas como unidad. [Las abreviaturas son las siguientes (EY: especies endémicas exclusivas de Yungas; Y+OE: especies presentes en Yungas y otros ambientes; NBY: especies no pertenecientes a las Yungas); (PRF: Bosque Pedemontano; MFSB: Bosque Montano (Selva Basal); MFSM: Bosque Montano (Selva de Mirtáceas); MCF: Bosque Montano Nublado; Gr: Pastizales; ArCH: Chaco árido o semiárido; HiCH: Chaco Montano o Serrano; Mo: Monte; Prpu: Prepuna)].

\begin{tabular}{|c|c|c|}
\hline \multicolumn{3}{|c|}{ Yungas as a unit $\left(2\right.$ areas, grid of $\left.1^{\circ}\right)$} \\
\hline Area & 2 (Fig. 2A) & 8 (Fig. 2B) \\
\hline EY & $14(48 \%)$ & $3(50 \%)$ \\
\hline $\mathrm{Y}+\mathrm{OE}$ & $13(45 \%)$ & $3(50 \%)$ \\
\hline NBY & $2(7 \%)$ & 0 \\
\hline Endemic spp. & 29 & 6 \\
\hline $\mathrm{E}$ & $15.30-16.61$ & $3.05-3.30$ \\
\hline PRF & $\begin{array}{c}\text { Spp. } 44,116,119,127,155,161,184,199,201,212,243,247,248, \\
251,257,271\end{array}$ & Spp. 119;127; 152, 257, 271 \\
\hline MFSB & $\begin{array}{c}\text { Spp. } 94,119,127,136,155,160,161,177,199,201,207,212,221, \\
243,245,247,248,249,257,271,286\end{array}$ & Spp. 118 \\
\hline MFSM & Spp. $84,94,118,119,136,155,160,207,221,249,251$ & Spp. 118 \\
\hline $\mathrm{MCF}$ & Spp. $118,249,286$ & \\
\hline Gr & Spp. $16,84,212,221,271$ & \\
\hline $\mathrm{ArCH}$ & Spp. $116,127,177,212,221,257$ & Spp. 271 \\
\hline $\mathrm{HiCH}$ & Spp. 161 & \\
\hline Mo & Spp. 177, 222, 249, 251 & \\
\hline Prpu & Spp. 16, 207, 222, 251 & \\
\hline Puna & Spp. $16,155,221,271$ & Spp. 152,271 \\
\hline
\end{tabular}

\& Goloboff (2004), implemented in the computer programs NDM and VNDM ver. 2.2 (Goloboff 2005).

The general idea of areas of endemism is not associated with a specific type of causal factor, but only with the existence of a common one; if a single factor affects the distribution of numerous groups of organisms at the same time, the distributions of those organisms are expected to show similar patterns, regardless of whether the causal factor is historical or ecological (Szumik \& Goloboff 2004). The method basically evaluates spatial concordance between two or more taxa for a given area (set of cells).

VNDM reads the records as coordinates and allows converting them easily into presence/ absence data on grids of different sizes. This method assigns, for each species, a score of endemicity (e) to sets of cells (= areas) according to how well the species distribution matches the area. For a given species, the score increases as fewer records exist outside the area, and more records exist inside. The total endemicity score (E) is the summation of the values for each species (e).

$$
\mathrm{E}=\sum \mathrm{e}_{\mathrm{i}}
$$

Where $e_{i}$ is the endemicity score (E) of individual species $i$. The value (e) for a given species varies between 0 (non scoring) and 1 (maximum score: species found in all cells of an area, and no cells outside). The method also allows distinguishing between actually observed records, probable, and inferred. See Szumik \& Goloboff (2004) for more details. 
The optimality criterion consists of selecting those areas with maximum value of endemicity.

In many studies of this kind, a single grid cell of $1^{\circ} \times 1^{\circ}$ is used. However, there is no formal argument to use only one grid size, which means that there is no criterion to select an accurate cell size for the study. Then, we analyze the data set in five different grid sizes, three of which are square $\left(1^{\circ}, 0.5^{\circ}\right.$, and $\left.0.25^{\circ}\right)$ and two are rectangular $\left(0.25^{\circ} \times 0.5^{\circ}\right.$ and $0.5^{\circ} \mathrm{x}$ $\left.0.25^{\circ}\right)$. Then, those areas which survive changes in grid size can be considered more strongly and clearly supported by the data (Aagesen et al. 2009). Additionally, different grid sizes will be able to identify different patterns if some of the taxonomic groups display congruence at different scales (see discussion and hypothetical examples in Casagranda et al. 2009, p. 272)

\section{RESULTS}

\section{The Yungas as a unit}

The insect data allow full recovery of the Argentinean Yungas as a biogeographic unit, in two main areas. One of these (Fig. 2A; E= 15.30-16.61 and 29 endemic species) includes roughly the whole Yungas. The other (Fig. 2B), with 10 endemic species, is included within the first one (Fig. 2A) and shares four species. Fig. 2 show the results for the $1^{\circ} \times 1^{\circ}$ grid, which clearly place the Yungas mostly beyond the level of resolution of such a loose grid. While Fig. 2 roughly follow the contour of the region generally recognized as Yungas, some cells are clearly outside those regions (e.g. the southeastern cell of Fig. 2A does not comprise any area of Yungas). The inclusion of those cells is not strongly supported by the data (i.e. removing them lowers the endemicity score no more than 1.5 to $3 \%$ of the score of the respective areas), but is supported nonetheless (i.e. the endemicity score does decrease when removing them). Were the available data much more detailed, this would probably be remedied by using smaller grid sizes, but (given the low density of the records known at the present), the smaller grid sizes produce very low scores of endemicity and a more diffuse identification of areas of endemism (vide infra). Concomitantly with this imperfect recognition of the Yungas, a small

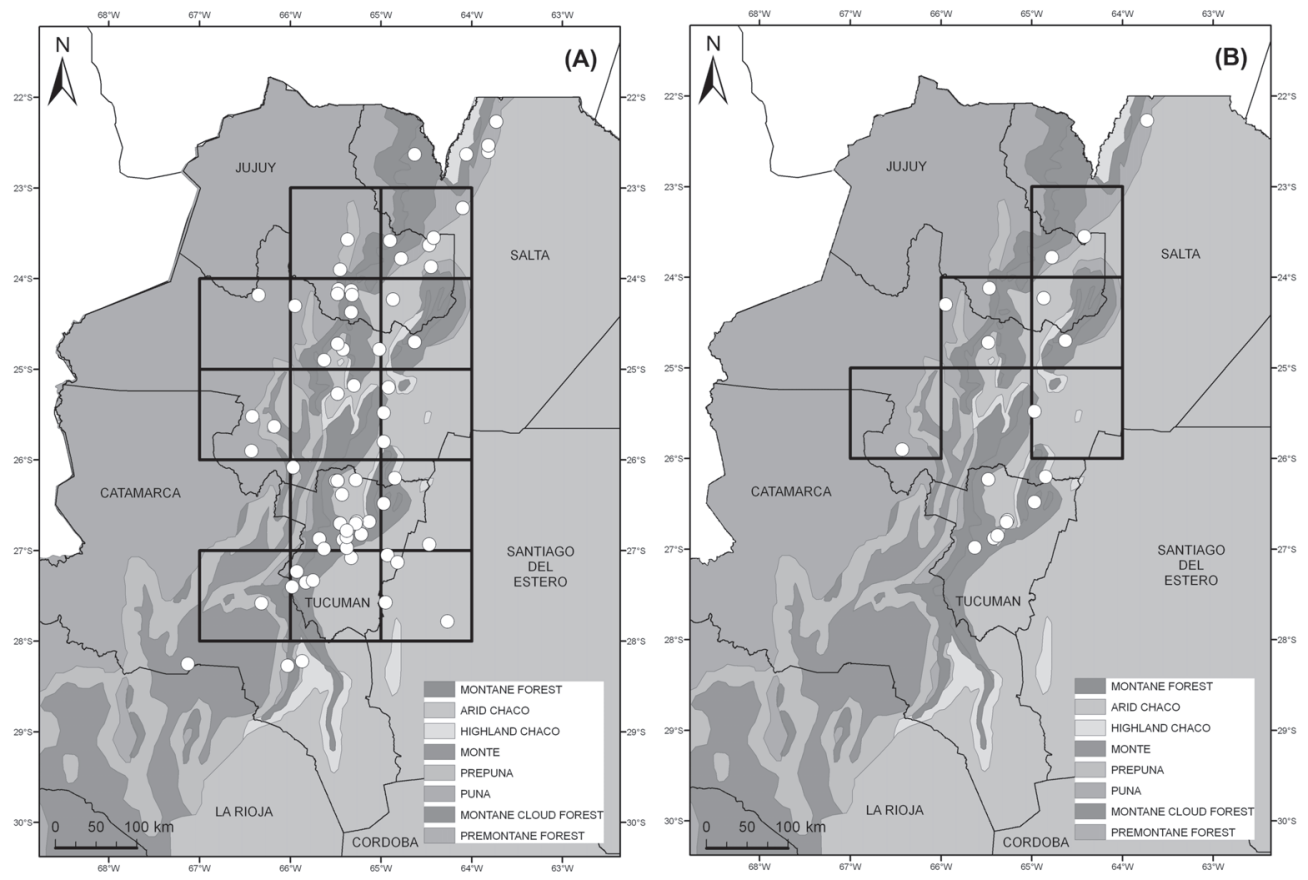

Fig. 2: The Argentinean Yungas have been fully recovered as a biogeographic unit it by means of NDM in two areas: $A$ and $B\left(\right.$ grid of $\left.1^{\circ}\right)$.

Las Yungas argentinas han sido recuperadas totalmente como una unidad biogeográfica por medio de NDM en dos áreas: A y B (celda de $1^{\circ}$ ). 
fraction of the species identified in our analysis as «endemic» for these two areas are in fact associated with other environments [Arid and semi-arid Chaco (dry forest), Montane or Highland Chaco, Monte (extensive shrubland), Prepuna and Puna (montane grasslands)] (Table 1). In part, another cause for these species to be identified as «endemic» is that many cells are large enough to contain records from both Yungas and non-Yungas habitats. Thus, the area of Fig. 2A has 14 species (48\% of its endemic species) only present in Yungas environment (Formicidae: three; Diptera: 10; Geometridae: one), 13 species which are also distributed in neighboring zones of other environments, and two species $(7 \%)$ never found in Yungas-type habitats (Table 1).

\section{Northern, central and southern Yungas}

Only one area depicts the northern sector (Fig. $3 \mathrm{~A}$, Table 2), with an endemicity value (E) of 1.67-1.92 and with only two endemic species. Both of these species are actually associated to Upper Montane Forest and Montane Cloud Forest. The area itself, which is in Alta Cuenca del Río Bermejo (Fig. 1), was found using a rectangular grid of $0.5^{\circ} \times 0.25^{\circ}$.
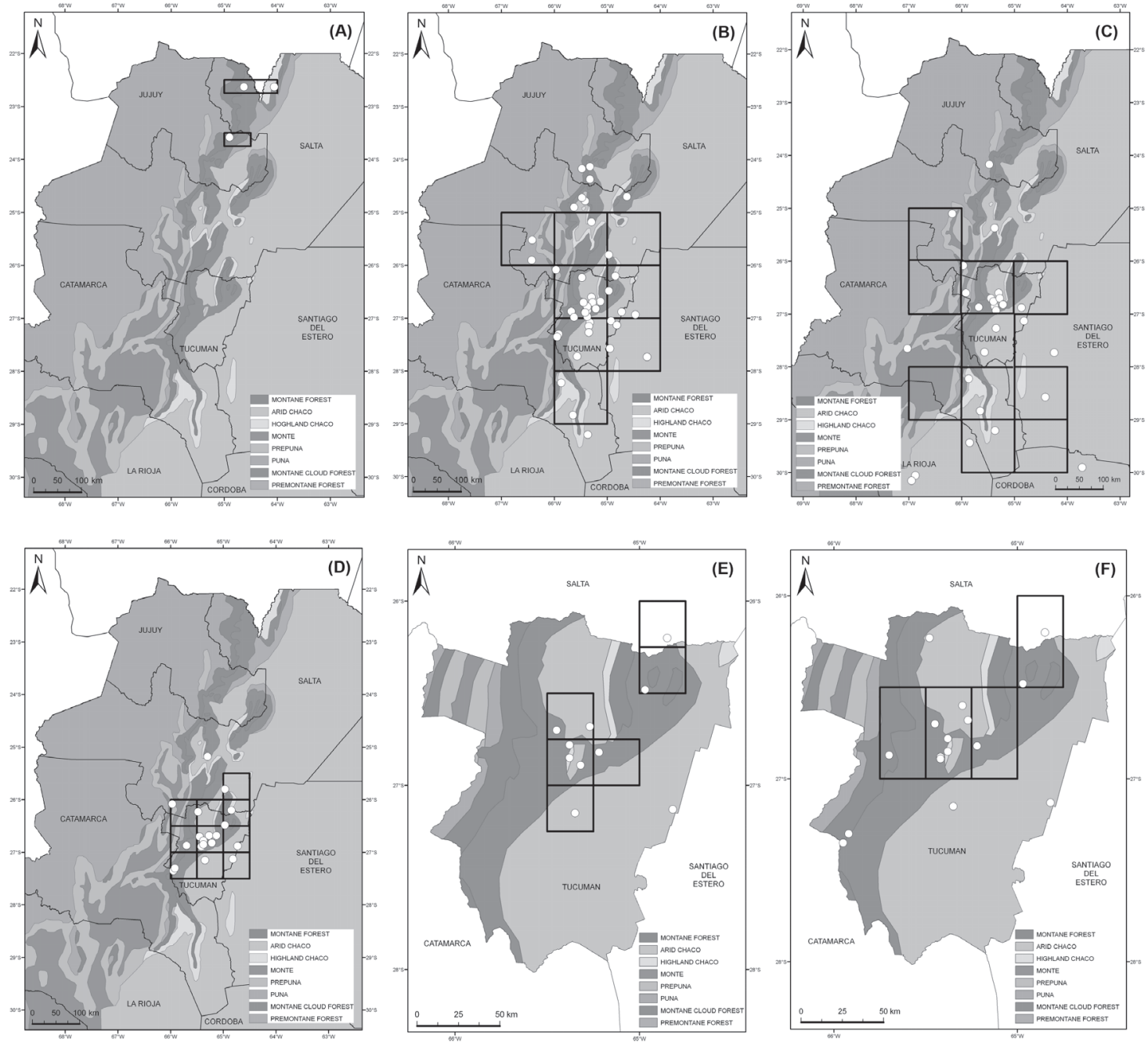

Fig. 3: Latitudinal sectors of the Argentinean Yungas. Northern sector: A $\left(0.5^{\circ} \times 0.25^{\circ}\right.$ grid $)$. Southern Sector: B ( $1^{\circ}$ grid $)$; C $\left(0.5^{\circ}\right.$ grid $)$; D $\left(0.25^{\circ}\right.$ grid $)$; E $\left(0.25^{\circ}\right.$ grid $)$; F $\left(0.25^{\circ}\right.$ x $0.5^{\circ}$ grid $)$.

Sector latitudinal de las Yungas Argentinas. Sector Norte: A (celda de $0.5^{\circ}$ x $0.25^{\circ}$ ). Sector Sur: B (celda de $1^{\circ}$ ); C (celda de $0.5^{\circ}$ ); D (celda de $0.25^{\circ}$ ); E (celda de $0.25^{\circ}$ ); F (celda de $0.25^{\circ} 6 \times 0.5^{\circ}$ ). 


\section{TABLE 2}

Specific composition of areas of endemism considering only northern sector

[Abbreviations as in Table 1].

Composición específica de áreas de endemismo resultantes considerando solo el sector norte [Abreviaturas como en Tabla 1].

Northern sector $\left(1\right.$ area, grid of $\left.0.5^{\circ} \times 0.25^{\circ}\right)$

\begin{tabular}{lc}
\hline Area & 9 (Fig. 3A) \\
EY & $2(100 \%)$ \\
Y+OE & 0 \\
NBY & 0 \\
Endemic species & 2 \\
E & $1.67-1.92$ \\
MFSB & Spp. 285, 287 \\
MFSM & Spp. 285, 287 \\
\hline
\end{tabular}

Unlike the northern sector, the southern sector appears under all grid sizes and is represented by seven areas. One area $\left(1^{\circ}\right.$ grid $)$, which is the most inclusive (Fig. 3B), has an endemicity value (E) of 9.89-10.57 (Table 3, third column) and includes 19 endemic species, of which nine species (Table 3; Formicidae: 1; Diptera: 5; Noctuidae: 2; Geometridae: 1) are restricted to Yungas environments, seven are present in Yungas and other environments (Grasslands, Arid and semi-arid Chaco, Monte and Puna), and three species occur only in environments outside Yungas (Grasslands, Arid and semi-arid Chaco, Montane or Highland Chaco and Monte).

In turn, another area $\left(1^{\circ}\right.$ grid) covers the same surface as the previous one except for central Salta (Fig. 3C). It is defined by 10

TABLE 3

Specific composition of areas of endemism considering only southern sector [Abbreviations as in Table 1].

Composición específica de áreas de endemismo resultantes considerando solo el sector sur [Abreviaturas como en Tabla 1].

\begin{tabular}{|c|c|c|c|c|c|c|c|}
\hline \multicolumn{8}{|c|}{ Southern sector (7 areas) } \\
\hline Area & 1 & 3 (Fig. 3B) & 14 (Fig. 3C) & 2 (Fig. 3D) & 2 (Fig. 3E) & 8 & 7 (Fig. 3F) \\
\hline Grid & $0.25^{\circ}$ & $1^{\mathrm{o}}$ & $1^{\circ}$ & $0.5^{\circ}$ & $0.25^{\circ}$ & $0.25^{\circ} \times 0.5^{\circ}$ & \\
\hline EY & $3(100 \%)$ & $9(47 \%)$ & $2(20 \%)$ & $6(67 \%)$ & $3(75 \%)$ & $6(75 \%)$ & $6(75 \%)$ \\
\hline $\mathrm{Y}+\mathrm{OE}$ & 0 & $7(37 \%)$ & $3(30 \%)$ & $2(22 \%)$ & $1(25 \%)$ & $2(25 \%)$ & $2(25 \%)$ \\
\hline NBY & 0 & $3(16 \%)$ & $5(50 \%)$ & $1(11 \%)$ & 0 & 0 & 0 \\
\hline $\mathrm{E}$ & 2.18 & $9.89-10.57$ & $3.84-4.09$ & $4.68-4.93$ & 2.56 & 4.94-5.19 & $3.47-3.72$ \\
\hline PRF & $\begin{array}{l}\text { Spp. } 169 \\
278\end{array}$ & $\begin{array}{c}\text { Spp. } 44,116,119, \\
169,214,271 \\
278,281,288\end{array}$ & $\begin{array}{l}\text { Spp. } 180,268, \\
272,281\end{array}$ & $\begin{array}{c}\text { Spp. } 44,111 \\
169,214,237 \\
278,288\end{array}$ & $\begin{array}{l}\text { Spp. } 167 \\
169,237\end{array}$ & $\begin{array}{l}\text { Spp. 111, 167, } \\
169,214,237, \\
278,288\end{array}$ & $\begin{array}{c}\text { Spp. } 111,167, \\
169,214,237, \\
278,288\end{array}$ \\
\hline MFSB & $\begin{array}{l}\text { Spp. } 153 \\
169,278\end{array}$ & $\begin{array}{c}\text { Spp. } 119,136,153, \\
169,214,221,245, \\
249,263,270,271, \\
278,288\end{array}$ & Spp. 180,263 & $\begin{array}{l}\text { Spp. } 153,169, \\
214\end{array}$ & Spp. 153 & $\begin{array}{l}\text { Spp. } 153,169, \\
214,237,278, \\
288\end{array}$ & $\begin{array}{l}\text { Spp. } 153,169, \\
214,237,278, \\
288\end{array}$ \\
\hline MFSM & Spp. 278 & $\begin{array}{l}\text { Spp. } 119,136 \\
221,249\end{array}$ & Spp. 272 & & & & \\
\hline $\mathrm{MCF}$ & & $\begin{array}{l}\text { Spp. } 214,249 \text {, } \\
263,281\end{array}$ & $\begin{array}{c}\text { Spp. } 263,272, \\
281\end{array}$ & Spp. 214 & & & \\
\hline $\mathrm{Gr}$ & & Spp. 168, 221, 271 & Spp. 168,180 & Spp. 111,178 & & Spp. 111 & Spp. 111 \\
\hline $\mathrm{ArCH}$ & & $\begin{array}{c}\text { Spp. } 116,178,217 \\
221,263,270\end{array}$ & $\begin{array}{l}\text { Spp. } 168,180, \\
217,266,268, \\
272,282\end{array}$ & & & & \\
\hline $\mathrm{HiCH}$ & & Spp. 168,217 & Spp. 168,217 & & Spp. 167 & Spp. 167 & Spp. 167 \\
\hline Mo & & Spp. 178,249 & Spp. 260, 266 & Spp. 178 & & & \\
\hline Prpu & & & Spp. 272,282 & & & & \\
\hline Puna & & Spp. 221,271 & & & & & \\
\hline
\end{tabular}


endemic species (E: 3.84-4.09), only two of which are restricted to Yungas habitats (Table 3 , fourth column).

When using a $0.5^{\circ}$ grid, the southern sector is better defined. In effect, the area represented in Fig. 3D, has an E: 4.68-4.93, and nine endemic species (Table 3, fifth column). It is the only one, which identifies the southern sector as a continuous homogeneous surface with six species $(67 \%)$ occurring exclusively in Yungas environment, two species (22\%) in Yungas and other environments and one species (11\%) outside Yungas (Table 3, fifth column). When using smaller grids $\left(0.25^{\circ} ; 0.25^{\circ} \times 0.5^{\circ}\right)$, the continuous surface in the $0.5^{\circ}$ grid appears as two areas partially overlapping (Figs. 3E, 3F) corresponding to southern Yungas of Salta and Yungas of Tucumán, respectively.

The combination of the northern and central sectors as an area (Fig. 4A) appears only under a $1^{\circ}$ grid with an endemicity value (E) of 3.503.75. Five species are identified as endemic (Table 4): two (40\%) restricted to Upper Montane Forest and Montane Cloud Forest and three $(60 \%)$ in Yungas as well as other environments.
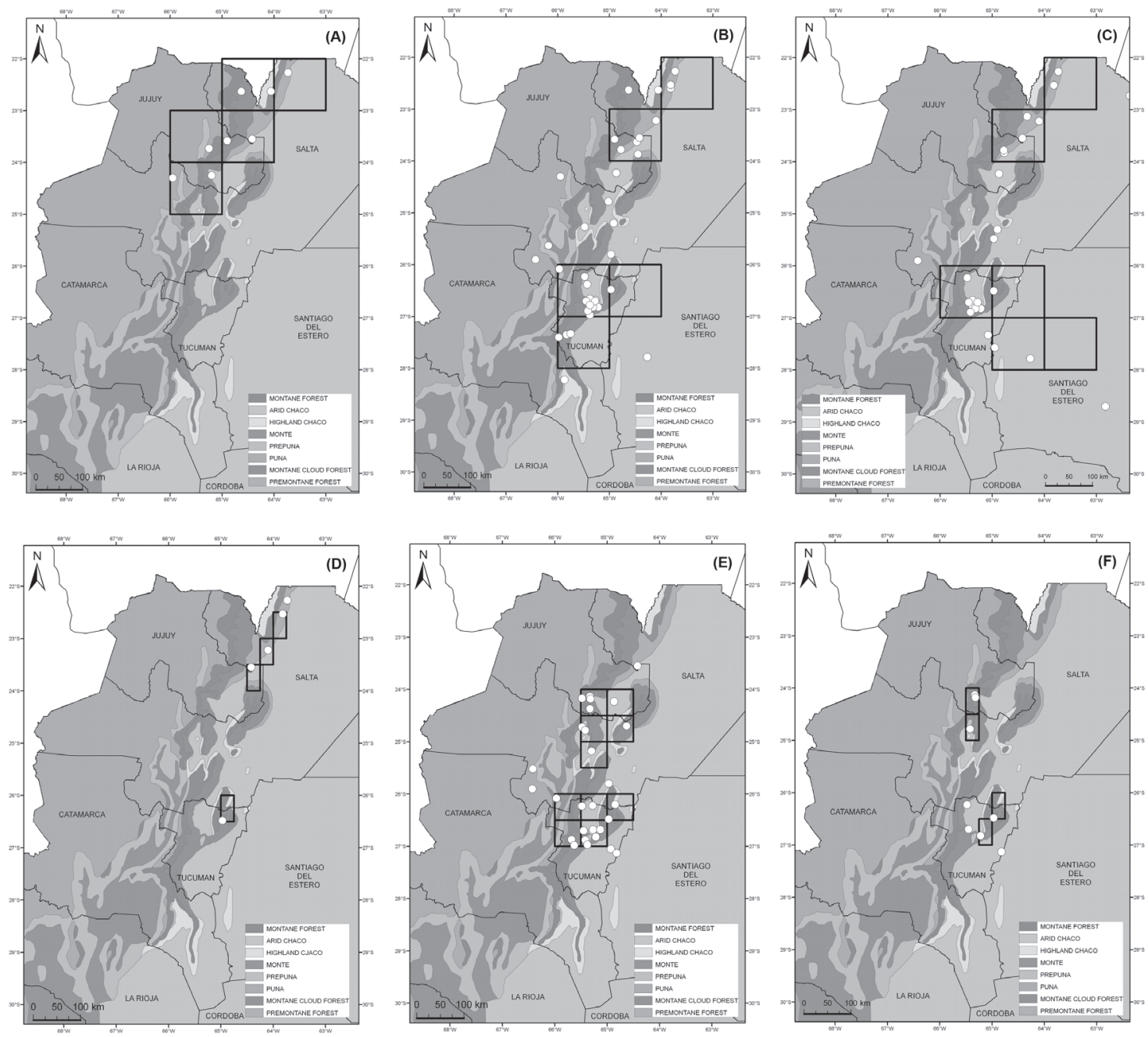

Fig. 4: Combinations between latitudinal sectors of the Argentinean Yungas. A, Northern and central sectors: ( $1^{\circ}$ grid $)$; Northern and southern sectors: $\mathrm{B}$ and $\mathrm{C}\left(1^{\circ}\right.$ grid $) ; \mathrm{D}\left(0.25^{\circ} \times 0.5^{\circ}\right.$ grid $)$. Central and southern sectors of Yungas as seen in $0.5^{\circ}$ grid and $0.25^{\circ} \times 0.5^{\circ}$ grid.

Combinaciones entre sectores latitudinales de las Yungas argentinas. A, Sectores Norte y Central: (celda de $1^{\circ}$ ); Sectores Norte y Sur: B y C (celda de $1^{\circ}$ ); D (celda de $\left.0.25^{\circ} \times 0.5^{\circ}\right)$. Sectores Central y Sur de las Yungas en celdas de $0.5^{\circ}$ y $0.25^{\circ}$ x $0.5^{\circ}$. 


\section{TABLE 4}

Specific composition of areas of endemism considering combination of northern and central sectors [Abbreviations as in Table 1].

Composición específica de áreas de endemismo resultantes considerando la combinación de los sectores norte y central [Abreviaturas como en Tabla 1].

\begin{tabular}{lc}
\hline Northern sector - central sector (1 area) \\
\hline Area & 13 (Fig. 4A) \\
Grid & $1^{\circ}$ \\
EY & $2(40 \%)$ \\
Y+OE & $3(60 \%)$ \\
NBY & 0 \\
Endemic spp. & 5 \\
E & $3.50-3.75$ \\
PRF & Spp. 152, 171 \\
MFSM & Spp. 285, 287 \\
MCF & Spp. 285, 287, 289 \\
ArCH & Spp. 171 \\
Puna & Spp. 152,289 \\
\hline
\end{tabular}

The combination of northern and southern sectors appears recognized in three grid sizes $\left(1^{\circ}, 0.5^{\circ}\right.$ and $\left.0.25^{\circ} \times 0.5^{\circ}\right)$ with seven areas altogether (Table 5). This combination has already been proposed as an area of high density of endemism, on the basis of qualitative analyses (Brown et al. 2001). The species that give score to this combination do not define each sector separately. Furthermore, they are completely different from those that define the combination of central and southern sectors, with the exception of one shared species.

The two areas in the Figs. $4 \mathrm{~B}$ and $4 \mathrm{C}\left(1^{\circ}\right.$ grid) share four cells and seven endemic species: five belong exclusively to the Yungas and associated to Premontane and Montane Forests (Selva Basal), and two belong to both Yungas and other surrounding environments. The first area has 14 species identified as

TABLE 5

Specific composition of areas of endemism considering combination of northern and southern sectors [Abbreviations as in Table 1].

Composición específica de áreas de endemismo resultantes considerando los sectores norte y sur combinados [Abreviaturas como en Tabla 1].

\begin{tabular}{|c|c|c|c|c|c|c|c|}
\hline \multicolumn{8}{|c|}{ Northern sector - southern sector ( 7 areas) } \\
\hline Area & 9 (Fig. 4B) & 10 (Fig. 4C) & 6 & 7 & 8 & 7 & 11 (Fig. 4D) \\
\hline Grid & $1^{\mathrm{o}}$ & $1^{\mathrm{o}}$ & $0.5^{\circ}$ & $0.5^{\circ}$ & $0.5^{\circ}$ & $0.25^{\circ} \times 0.5^{\circ}$ & $0.25^{\circ} \times 0.5^{\circ}$ \\
\hline EY & $12(86 \%)$ & $5(63 \%)$ & $4(67 \%)$ & $3(75 \%)$ & $3(100 \%)$ & $2(100 \%)$ & $3(100 \%)$ \\
\hline $\mathrm{Y}+\mathrm{OE}$ & $2(14 \%)$ & $3(37 \%)$ & $2(33 \%)$ & $1(25 \%)$ & 0 & 0 & 0 \\
\hline NBY & 0 & 0 & 0 & 0 & 0 & 0 & 0 \\
\hline $\mathrm{E}$ & $10.27-10.52$ & $5.59-5.84$ & $3.03-3.28$ & $2.77-3.02$ & $2.02-2.27$ & $1.42-1.67$ & $1.77-2.02$ \\
\hline PRF & $\begin{array}{c}\text { Spp. 127, 131, } \\
155,161,199, \\
201,212,243, \\
247,248,251, \\
257,276\end{array}$ & $\begin{array}{c}\text { Spp. 19, 131, } \\
199,201 \\
212,243 \\
257,276\end{array}$ & $\begin{array}{c}\text { Spp. 127, 199, } \\
201,247,251\end{array}$ & $\begin{array}{c}\text { Spp. } 243248 \\
257\end{array}$ & Spp. 199, 243 & Spp. 199, 243 & $\begin{array}{c}\text { Spp. } 127,201, \\
247\end{array}$ \\
\hline MFSB & $\begin{array}{c}\text { Spp. 127, 131, } \\
155,161,199, \\
201,212,243, \\
247,248,257, \\
276,286\end{array}$ & $\begin{array}{l}\text { Spp. 131, } \\
199,201, \\
212,243, \\
257,276\end{array}$ & $\begin{array}{l}\text { Spp. 127, 199, } \\
201,247,286\end{array}$ & $\begin{array}{c}\text { Spp. } 243,248 \\
257,286\end{array}$ & Spp. 199, 243 & Spp. 199, 243 & $\begin{array}{c}\text { Spp. } 127,201, \\
247\end{array}$ \\
\hline MFSM & $\begin{array}{c}\text { Spp. } 155,251, \\
276\end{array}$ & Spp. 276 & Spp. 251 & Spp. 286 & Spp. 286 & & \\
\hline $\mathrm{MCF}$ & Spp. 286 & & Spp. 286 & Spp. 286 & Spp. 286 & & \\
\hline \multicolumn{8}{|l|}{$\mathrm{Gr}$} \\
\hline $\mathrm{ArCH}$ & Spp. 276 & Spp. 19, 212, 276 & Spp. 127 & Spp. 257 & & & \\
\hline \multicolumn{8}{|l|}{$\mathrm{HiCH}$} \\
\hline Mo & Spp. 251 & & Spp. 251 & & & & \\
\hline
\end{tabular}


endemic, $86 \%$ of which are exclusively associated to Yungas (Table 5, second column), whereas the second area has 8 species identified as endemic, $63 \%$ of which are exclusively associated to Yungas (Table 5, third column). With a few differences in endemic species composition and/or extension, it is clear that the same pattern is obtained with different grid sizes (Fig. 4D).

The combination of the central and southern sectors appears in areas on three grids (Table 6). In fact, the association of Premontane and Montane Forests of both sectors was proposed by Morales et al. (1995). The 15 endemic species which give score to this combination, also define other areas (e.g. southern sector, the Yungas). Two areas $\left(0.5^{\circ}\right.$ grid) (Fig. 4E) are disjoint units and include the Montane Forest in the central sector and patches of Montane Forest in the southern sector. Regarding the smaller grids, although there is a reduction of the surface and numbers of endemic species, the pattern is similar to that for the $0.5^{\circ}$ grid (Fig. 4F).

\section{Other biogeographic units}

A combination of patches of Yungas and Oriental Chaco (Fig. 5A) can be seen in all grid sizes. Some tree species of Premontane Forest that occasionally appear within Chaco have been reported (Prado 1995); they are usually related to gallery forests and they are considered of 'non-chacoan lineage' (Adámoli et al. 1972) or as 'subtropical forest transchacoan elements' (Morello \& Adámoli 1974). During the climatic fluctuations of the Pleistocene, according to Prado (1995), the Yungas covered the whole of northern Argentina (reaching Córdoba province to the South) and these patches are remnants of that formation. Here, the area seen in Fig. 5B $\left(1^{\circ}\right.$ grid) shows this combination of patches of Yungas, Chaco and Espinal.

Only in the smaller grid sizes $\left(0.25^{\circ}, 0.25^{\circ}\right.$ $\left.\mathrm{x} 0.5^{\circ}, 0.5^{\circ} \mathrm{x} 0.25^{\circ}\right)$ is a combination of Yungas and Paranaense (NE of Misiones province) forests recognized. This combination probably represents neotropical tails which are the southern section of the Neotropical region. In the $1^{\circ} \times 1^{\circ}$ grid this combination appears together with Oriental Chaco cells.

Although the analysis of the formation of the Paranaense Forest is not within the scope of the present paper, it is identified in all grid sizes (Fig. 5C), except the $0.25^{\circ} \times 0.25^{\circ}$ grid. Also, there are areas that include patches of Misiones Forest and Oriental Chaco, or Misiones Forest and Espinal.

\section{Altitudinal levels}

Sixty-nine species of insects are recorded in the Yungas, 23 of which are endemic to this environment (Table 7). From the analysis of these records it can be concluded that each altitudinal level has some exclusive species, while some others are shared by two altitudinal levels (Table 7). This qualitative assessment is partially supported by the endemicity analysis. The three altitudinal levels are present in one area $\left(0.5^{\circ}\right.$ grid $)$ (southern and northern sectors) sharing three endemic species. According to our results, the Premontane Forest is always associated to Selva Basal (Lower Montane Forest) or to the whole Montane Forest (Selva basal and Selva de Mirtáceas). Finally, the Montane Forest is the only altitudinal level that stands on its own in this analysis $\left(0.5^{\circ} \times 0.25^{\circ}\right.$ grid).

\section{DISCUSSION}

In agreement with the proposal of Morrone $(2000,2001,2006)$ our results indicate that the Yungas can be characterized as a biogeographic unit with its own identity, where insects could be an excellent tool to identify areas of endemism. The extensive spatial concordance between our results and previous proposals for the Yungas indicate that insect data, even if fragmentary, can be used as reliable indicators of areas of endemism. The degree of spatial concordance between the areas recognized by our quantitative analysis and previous qualitative hypotheses could hardly be the result of chance, which would be an astonishing coincidence.

The use of the quantitative method to identify areas of endemism developed by Szumik et al. (2002) and Szumik \& Goloboff (2004) has many advantages. First, the discontinuous distributional pattern of the Yungas, due to habitat fragmentation, can be recognized as such, given that this method identifies disjoint areas. Second, this method also allows the identification of partially 

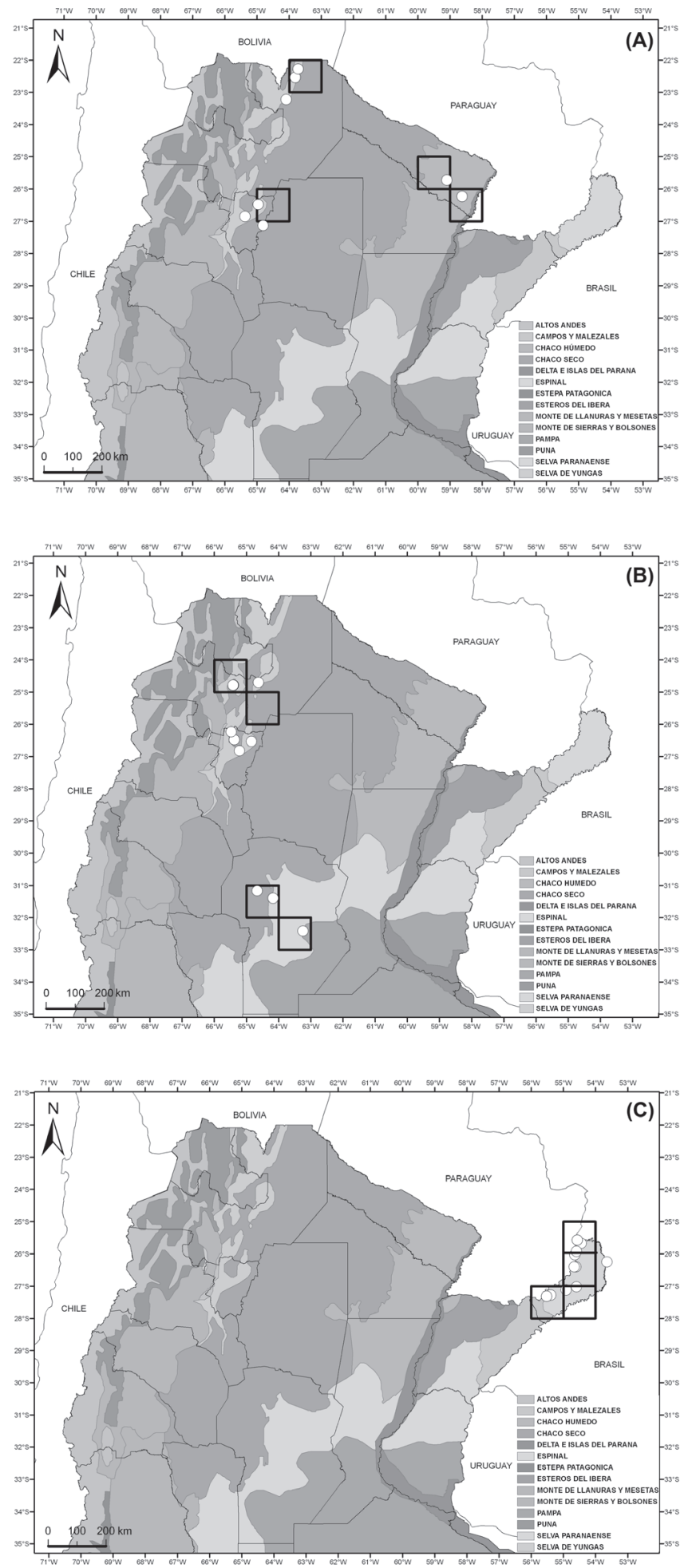

Fig. 5: Other biogeographic units. A, Patches of Yungas and Humid to sub-humid or Oriental Chaco $\left(1^{\circ}\right.$ grid $)$; B, combination of patches of Yungas + Chaco + Espinal $\left(1^{\circ}\right.$ grid $)$; , Misiones Forest $\left(1^{\circ}\right.$ grid $)$.

Otras unidades biogeográficas. A, Parches de Yungas y Chaco Oriental o Chaco Húmedo a sub-húmedo (celda de $1^{\circ}$ ); B, combinación de parches de Yungas + Chaco + Espinal $\left(\right.$ celda de $\left.1^{\circ}\right)$; C, Selva Misiones $\left(\right.$ celda de $\left.1^{\circ}\right)$. 
TABLE 6

Specific composition of areas of endemism considering combination of central and southern sectors of Yungas [Abbreviations as in Table 1].

Composición específica de áreas de endemismo resultantes considerando los sectores central y sur combinados [Abreviaturas como en Tabla 1].

\begin{tabular}{|c|c|c|c|c|c|c|c|c|}
\hline \multicolumn{9}{|c|}{ Central sector - southern sector ( 8 areas) } \\
\hline Area & 3 & 5 & 5 & 9 (Fig. 4E) & 10 & 12 & 4 (Fig. 4F) & 6 \\
\hline Grid & $0.5^{\circ}$ & $0.5^{\circ}$ & $0.5^{\circ} \times 0.25^{\circ}$ & $0.5^{\circ} \times 0.25^{\circ}$ & $0.5^{\circ} \times 0.25^{\circ}$ & $0.5^{\circ} \times 0.25^{\circ}$ & $0.5^{\circ} \times 0.25^{\circ}$ & $0.5^{\circ} \times 0.25^{\circ}$ \\
\hline EY & $7(54 \%)$ & $3(43 \%)$ & $1(50 \%)$ & $4(100 \%)$ & $3(100 \%)$ & $3(75 \%)$ & $1(50 \%)$ & $2(100 \%)$ \\
\hline $\mathrm{Y}+\mathrm{OE}$ & $6(46 \%)$ & $3(43 \%)$ & $1(50 \%)$ & 0 & 0 & $1(25 \%)$ & $1(50 \%)$ & 0 \\
\hline NBY & 0 & $1(14 \%)$ & 0 & 0 & 0 & 0 & 0 & 0 \\
\hline $\mathrm{E}$ & $6.68-6.93$ & $3.60-3.85$ & $1.67-1.92$ & $2.25-2.50$ & $2.00-2.25$ & $1.91-2.16$ & $1.75-2.0$ & $1.43-1.68$ \\
\hline PRF & $\begin{array}{c}\text { Spp. } 44,119 \\
271\end{array}$ & & & Spp. 184 & Spp. 44, 184 & & & \\
\hline MFSB & $\begin{array}{c}\text { Spp. } 94, \\
119,127 \\
136,160 \\
177,184 \\
221,245 \\
249,27\end{array}$ & $\begin{array}{c}\text { Spp. 127, } \\
136,160, \\
207,221, \\
249\end{array}$ & Spp. 94 & $\begin{array}{c}\text { Spp. } 136,160 \\
245\end{array}$ & Spp. 245 & $\begin{array}{c}\text { Spp. } 136,177 \\
245,249\end{array}$ & Spp. 94, 177 & Spp. 136,160 \\
\hline MFSM & $\begin{array}{c}\text { Spp. } 84,94 \\
119,136 \\
160,221 \\
24\end{array}$ & $\begin{array}{c}\text { Spp. 136, } \\
160,221 \\
249\end{array}$ & Spp. 84, 94 & Spp. 136,160 & & Spp. 136, 249 & Spp. 94 & Spp. 136,160 \\
\hline $\mathrm{MCF}$ & Spp. 249 & Spp. 249 & & & & Spp. 249 & & \\
\hline $\mathrm{Gr}$ & $\begin{array}{c}\text { Spp. } 84,221 \\
221\end{array}$ & & Spp. 84 & & & & & \\
\hline $\mathrm{ArCH}$ & Spp. 127,177 & Spp. 127 & & & & Spp. 177 & Spp. 177 & \\
\hline $\mathrm{HiCH}$ & & & & & & & & \\
\hline Mo & Spp. 177, 249 & Spp. 221, 249 & & & & & Spp. 177 & \\
\hline Prpu & & Spp. 207, 221 & & & & & & \\
\hline
\end{tabular}

overlapping areas when they have different sets of endemic species. Third, the programs used offer facilities that considerably simplify summarizing the results. In some cases, many sets differ simply by one or two cells, and have their scores given by the same species; with these programs, similar areas that differ by one or a few cells could be considered as a unit.

Another aspect studied here is the effect of the grid cell size on the results. The present analysis suggests that the use of several grid sizes is crucial; medium and small sizes in particular are highly recommended as both identify seemingly different patterns.

A total of 26 areas related to Yungas have shown 23 species (in 14 families) as endemic restricted to Yungas environment (Table 2), and
46 species (in 10 families) as endemic present in Yungas and surrounding habitats (Chacoan and Parana subregions, sensu Morrone 2006).

According to our results, the use of insect data to identify areas of endemism has shown to have both strengths and weaknesses. It is evident that the knowledge of these groups is too superficial for analyses to resolve the finer details and boundaries of the areas in question. Until the knowledge of these groups in the tropical and subtropical areas is as detailed as that of the butterflies of Europe (e.g. as in Kudrna 2002) little more can be discussed, but that might take decades or centuries. Considering that even the current fragmentary knowledge of these groups allows to identify, if perhaps somewhat imprecisely, the main areas 
of endemism recognized before, insects are clearly a promising line of evidence. As research and collecting on these groups accumulates, they will probably be one of the key factors in identifying the main biotic regions of the Neotropics.

TABLE 7

Faunistic composition of endemic Insects from Yungas of Argentina. Abbreviations of altitudinal levels: PRF, Premontane Forest; MOF, Montane Forest; MCF, Montane Cloud Forest. Note: * indicate endemic species that belong exclusively to the Yungas environment.

Composición faunística de insectos endémicos de las Yungas de Argentina. Abreviaturas de niveles altitudinales: PRF, Bosque Pedemontano; MOF, Bosque Montano; MCF, Bosque Montano Nublado. Nota: * indica especies endémicas que se encuentran exclusivamente en el ambiente Yungas.

\begin{tabular}{|c|c|c|}
\hline Species & Family & Altitudinal level \\
\hline Adejeania andina* & Tachinidae & PRF-MOF \\
\hline Argentinomyia maculatus & Syrphidae & PRF-MOF \\
\hline Argentinomyia neotropicus & Syrphidae & PRF-MOF-MCF \\
\hline Baccha ida & Syrphidae & PRF-MOF \\
\hline Baccha titania* & Syrphidae & PRF-MOF \\
\hline Baccha zit & Syrphidae & MOF \\
\hline Baccha zoroaster & Syrphidae & PRF-MOF \\
\hline Baniana triangulifera & Noctuidae & PRF-MOF \\
\hline Bassania jocosa* & Geometridae & MOF-MCF \\
\hline Bassania schreiteri* ${ }^{*}$ & Geometridae & PRF-MOF \\
\hline Bassania tucumana* & Geometridae & MOF-MCF \\
\hline Bibio wulpi* & Bibionidae & MOF \\
\hline Bryolymnia dido & Noctuidae & MOF-MCF \\
\hline Camponotus leydigi & Formicidae & PRF-MOF \\
\hline Camponotus propinquus & Formicidae & PRF-MOF \\
\hline Cephalotes pilosus & Formicidae & PRF \\
\hline Clythia thomseni & Platypezidae & MOF \\
\hline Coxina turibia* & Noctuidae & PRF-MOF \\
\hline Crematogaster Euterpe* & Formicidae & PRF \\
\hline Crematogaster rudis & Formicidae & PRF \\
\hline Crematogaster scapamaris & Formicidae & MOF \\
\hline Cyphomyrmex lilloanus & Formicidae & PRF \\
\hline Dicladocera molle & Tabanidae & MOF \\
\hline Dilophus pectoralis & Bibionidae & MOF \\
\hline Dorylas lindneri & Pipunculidae & PRF \\
\hline Elaphria atrisigna & Noctuidae & PRF \\
\hline Epistrophe roburoris* & Syrphidae & MOF \\
\hline Esenbeckia argentina & Tabanidae & PRF-MOF \\
\hline Fannia coxata* & Fanniidae & MOF \\
\hline Fidena longipalpis & Tabanidae & PRF-MOF \\
\hline Gowdeyana vitrisetosus* & Stratiomyidae & PRF-MOF \\
\hline Hippelates femoralis & Chloropidae & PRF \\
\hline Hygrochroma subvenusta* & Geometridae & MOF-MCF \\
\hline Hypoponera fiebrigi & Formicidae & PRF-MOF \\
\hline Hystricia palpina & Tachinidae & PRF \\
\hline Lastaurus tricolor* & Asilidae & PRF-MOF \\
\hline Leia fasciata & Mycetophilidae & PRF \\
\hline Lycopale vittata & Syrphidae & MOF \\
\hline Macapta dileuca & Noctuidae & MOF \\
\hline Macapta grisea & Noctuidae & PRF-MOF \\
\hline Matigramma nítida* & Noctuidae & PRF-MCF \\
\hline Matopo giacomelli & Noctuidae & PRF-MOF-MCF \\
\hline Metadorylas tucumanus* & Pipunculidae & PRF \\
\hline
\end{tabular}


Micropeza dorsalis*

Micropeza maculiceps*

Micropeza marginatus*

Micropeza nigrinus

Micropeza similis

Micropeza tarsalis

Ochetomyrmex argentinus

Oxydia optima

Paralimna pectinata

Paralimna sticta*

Paratrechina silvestrii

Pheidole carapunco

Pheidole lilloi

Pheidole subaberrans*

Pipunculus subjectus

Pipunculus tucumanus

Plecia grisea

Plesiomma caedens

Rhachoepalpus cinereus

Solenopsis angulata

Systropus conopoides*

Trachymyrmex pruinosus

Tucumyia angustigena

Tucumyia pollinosa*

Wasmannia sulcaticeps*

Xanthandrus nitidulus
Micropezidae

Micropezidae

Micropezidae

Micropezidae

Micropezidae

Micropezidae

Formicidae

Geometridae

Ephydridae

Ephydridae

Formicidae

Formicidae

Formicidae

Formicidae

Pipunculidae

Pipunculidae

Bibionidae

Asilidae

Tachinidae

Formicidae

Bombylidae

Formicidae

Asteiidae

Asteiidae

Formicidae

Syrphidae
MOF

PRF-MOF

PRF-MOF

MOF-MCF

PRF-MOF

PRF-MOF

PRF

$\mathrm{MCF}$

PRF-MOF

$\mathrm{MOF}$

PRF-MOF

MOF

PRF

MOF

PRF-MOF

PRF-MOF

PRF-MOF-MCF

PRF-MOF

MOF

PRF

PRF-MOF

PRF

MOF

PRF-MOF

MOF-MCF

PRF-MOF

\section{ACKNOWLEDGEMENTS}

We thank to FONCyT (PICT 12605), Consejo de Investigaciones de la Universidad Nacional de Tucumán (CIUNT), and CONICET (PIP 6502) for support. A preliminary version of this paper was presented at the V Reunión Argentina de Cladística y Biogeografía (Salta, 2004) and the I Reunión de la Red CYTED para la Conservación e Informatización de Colecciones Biológicas (Buenos Aires, 2005); we thank the organizers, Fernando Lobo and Martín Ramírez, respectively and members of the audiences for discussion. Helpful comments from Lone Aagesen are greatly appreciated. Luisa Montivero helped with our English.

\section{LITERATURE CITED}

AAGESEN L, C SZUMIK, FO ZULOAGA \& O MORRONE (2009) Quantitative biogeography in the South America highlands - recognizing the Altoandina, Puna and Prepuna through the study of Poaceae. Cladistics 25: 295-310.

ADÁMOLI J, R NEUMANN, AD RATIER DE COLINA \& J MORELLO (1972) El Chaco aluvional salteño (Convenio INTA-Prov. de Salta). Revista de
Investigaciones Agropecuarias, INTA, Serie 3, Clima y Suelo 9: 165-237.

BRANDÃO CRF (1991) Adendos ao catálogo abreviado das formigas da Regiao Neotropical. Revista Brasileira de Entomologia 35: 319-412.

BROWN AD (1995) Las selvas de montaña del noroeste de Argentina: problemas ambientales e importancia de su conservación. In: Brown AD \& HR Grau (eds) Investigación, conservación y desarrollo en selvas subtropicales de montañas: 9-18. Laboratorio de Investigaciones Ecológicas de las Yungas (UNT), Tucumán, Argentina.

BROWN AD, HR GRAU, LR MALIZIA \& A GRAU (2001) Argentina. In: Kappelle M \& AD Brown (eds) Bosques nublados del geotrópico: 623-659. Instituto Nacional de Biodiversidad (INBio), Santo Domingo de Heredia, Costa Rica.

BROWN AD \& ED RAMADORI (1989) Patrón de distribución, diversidad y características ecológicas de especies arbóreas de las selvas y bosques montanos del noroeste de la Argentina. Anales VI Congreso Forestal Argentino: 177-181.

CABRERA AL (1971) Fitogeografía de la República Argentina. Boletín de la Sociedad Argentina de Botánica 14: 1-42.

CABRERA AL (1976) Regiones fitogeográficas argentinas. In: Kugler WF (ed) Enciclopedia argentina de agricultura y jardinería II: 1-85. ACME, Buenos Aires, Argentina.

CABRERA AL \& A WILLINK (1973) Biogeografía de América Latina. Monografía 13, Serie de Biología, OEA, Washington DC. 120 pp.

CASAGRANDA MD, JS ARIAS, PA GOLOBOFF, C SZUMIK, LM TAHER, T ESCALANTE \& JJ 
MORRONE (2009) Proximity, interpenetration and sympatry: A reply to Dos Santos et al. Systematic Biology 58: 271-276.

CRISP MD, S LAFFAN, HP LINDER \& A MONRO (2001) Endemism in the Autralian flora. Journal of Biogeography 28: 183-198.

CUEZZO F (1998) Capítulo 42. Formicidae. In: Coscarón S \& JJ Morrone (eds) Biodiversidad de artrópodos argentinos, una perspectiva biotaxonómica: 452462. Ediciones SUR, La Plata, Argentina.

CUEZZO F, M LIZARRALDE DE GROSSO, F NAVARRO \& C SZUMIK (2007) Endemic insects from Yungas of Argentina. Zootaxa 1576: 63-67.

DOMÍNGUEZ MC, S ROIG-JUÑENT, JJ TASSIN, FC OCAMPO \& GE FLORES (2006) Areas of endemism of the patagonian steppe: An approach based on insect distributional patterns using endemicity analysis. Journal of Biogeography 33: 1527-1537.

FJELDSA J \& N KRABBE (1991) Birds of the high Andes. Zoological Museum, University of Copenhagen \& Apollo Books, Svendborg, Denmark. 880 pp.

GRAHAM A (1995) Development of affinities between Mexican/Central American and northern South American lowland and lower montane vegetation during the Tertiary. In: Churchill SP, H Balsev, E Forero \& JL Luteyn (eds) Biodiversity and conservation of Neotropical montane forest: 11-22. The New York Botanical Garden, New York, USA.

HUECK K (1978) Los bosques de Sudamérica. Ecología, composición e importancia económica, Sociedad Alemana de Cooperación Técnica Ltda (GTZ), Eschborn, Germany. 475 pp.

KEMPF WW (1972) Catálogo abreviado das formigas da Regiao Neotropical (Hymenoptera: Formicidae). Studia Entomologica 15: 3-343.

KUDRNA O (2002) The distribution atlas of European butterflies. Oedippus 20: 1-343.

LINDER P (2001) On areas of endemism, with an example from the African Restionaceae. Systematic Biology 50: 892-912.

LIZARRALDE DE GROSSO M (1989) Ephydridae de la República Argentina (Insecta-Diptera). Serie Monográfica y Didáctica $\mathrm{N}^{\circ} 3$. Facultad de Ciencias Naturales e IML. Editorial de la Universidad Nacional de Tucumán, Argentina. 93 pp.

LIZARRALDE DE GROSSO M (1998) Ephydridae. In: Coscarón S \& JJ Morrone (eds) Biodiversidad de artrópodos argentinos, una perspectiva biotaxonómica: 365-373. Ediciones SUR, La Plata, Argentina.

LÖWENBERG-NETO P \& CJ BARROS DE CARVALHO (2004) Análise Parsimoniosa de Endemicidade (PAE) na delimitação de áreas de endemismos: inferências para conservação da biodiversidade na Região Sul do Brasil. Naturaleza \& Conservação 2: 58-65.

MORALES JM, M SIROMBRA \& AD BROWN (1995) Riqueza de árboles en las Yungas argentinas. In: Brown AD \& HR Grau (eds) Investigación, conservación y desarrollo en selvas subtropicales de montañas: 163-174. Laboratorio de Investigaciones
Ecológicas de las Yungas (UNT), Tucumán, Argentina.

MORELLO J \& J ADÁMOLI (1974) Las grandes unidades de vegetación y ambiente del Chaco argentino. Segunda parte: vegetación y ambiente de la provincia del Chaco. Serie Fitogeográfica $N^{\circ} 13$ INTA, Buenos Aires. 130 pp.

MORRONE JJ (1994) On the identification of areas of endemism. Systematic Biology 43: 438-441.

MORRONE JJ (2000) A new regional biogeography of the Amazonian subregion, based mainly on animal taxa. Anales del Instituto de Biología de Universidad Autónoma de México, Zoología 71: 99-123.

MORRONE JJ (2001) Biogeografía de América Latina y el Caribe. M\&T-Manuales \& Tesis de la Sociedad Entomológica Aragonesa, vol. 3, Zaragoza. 148 pp.

MORRONE JJ (2006) Biogeographic areas and transition zones of Latin America and the Caribbean Islands based on analyses of the entomofauna. Annual Review of Entomology 51: 467-94.

PLATNICK NI (1991) On areas of endemism. Australian Systematic Botany 4: 11-12.

PAPAVERO N (1966-1984) A catalogue of the Diptera of the America South of the United States. Departamento de Zoologia, Secretaria de Agricultura, São Paulo, Brasil.

POOLE RW (1989) Lepidopterorum catalogus. (New Series). Fascicle 118. Noctuidae [in 3 parts] E.J.Brill/Flora and Fauna Publications, New York.

PRADO DE (1995) Selva Pedemontana: contexto regional y lista florística de un ecosistema en peligro. In: Brown AD \& HR Grau (eds) Investigación, conservación y desarrollo en selvas subtropicales de montañas: 19-52. Laboratorio de Investigaciones Ecológicas de las Yungas (UNT), Tucumán, Argentina.

PRADO DE \& PE GIBBS (1993) Patterns of species distributions in the dry seasonal forests of South America. Annals Missouri Botanical Garden 80: 902-927.

QUIJANO MA, R CALLEJAS \& DR MIRANDA (2006) Areas of endemism and distribution patterns for Neotropical Piper species (Piperaceae). Journal of Biogeography 33: 1266-1278.

ROVITO SM, MTK ARROYO \& P PLISCOFF (2004) Distributional modelling and parsimony analysis of endemicity of Senecio in the Mediterranean-type climate area of Central Chile. Journal of Biogeography 31: 1623-1636.

SCOBLE MJ (1999) Geometrid moths of the world: a catalogue (Lepidoptera: Geometridae), (2 volumes). CSIRO Publishing, Collingwood, Victoria, Australia. $1016 \mathrm{pp}$.

SZUMIK C \& PA GOLOBOFF (2004) Areas of endemism: an improved optimality criterion. Systematic Biology 53: 968-977.

SZUMIK C, F CUEZZO, PA GOLOBOFF \& A CHALUP (2002) An optimality criterion to determine areas of endemisms. Systematic Biology 51: 806-816.

WILLINK A (1991) Contribución a la zoogeografía de insectos argentinos. Boletín de la Academia Nacional de Ciencias (Argentina) 59: 125-147. 